\title{
Sustaining ECOWAS In The Dynamic Confluence Of Regional Market Constraints
}

Darlington Richards, Morgan State University, USA

Gladson Nwanna, Morgan State University, USA

\begin{abstract}
This paper discusses the Economic Community of West African States (ECOWAS) as a concept founded and deeply rooted in the market and economic integration of the participating countries, as well as a model frame for the larger, if more ambitious, integration of the entire continent. It contends that if effectively implemented, sub-Saharan Africa would experience a huge transition that would tremendously transform its participation in globalization so significantly than is otherwise the case today. In this paper, we outline the contending dynamics and constraints in the sub-region. From this premise, it focuses on the market integration challenges facing ECOWAS as it identifies the institutional, structural and infrastructural constraints, with their backgrounds and origins in the colonial antecedents of the member countries. It is our contention that effective economic integration (substantially lacking at present) requires the development of core human "facilitators", as well as institutional and infrastructural convergence and compatibility in functional market structures. While we note that the need, and indeed urgency, to fully integrate the sub-region is hampered by the lack of a realistic timetable or framework for implementation, we also note the lack of prioritization of integratable policy options. In this paper, however, we have not addressed what or which policy options should enjoy sequential priority in the realization of full economic integration, even though such criticality is noted. The failure of full economic integration more than 25 years after inception speaks to larger underlying constraint components within and without the sub-region that must be addressed. The futility of an integration initiate with such disparate and divergent in-country policy initiatives cannot be overemphasized. As a process, regional economic integration is a value-driven process that can potentially deliver benefits to consumers and present firms with new markets, as well as challenges. Hopefully, addressing these constraints would persuade a holistic and more optimistic assessment of the sub-region (as opposed to individual country assessment) as an alternative location that is sufficiently attractive in its competitive offer and sensitivity to Foreign Direct Investment.
\end{abstract}

Keywords: ECOWAS, Economic Union, West Africa, Economic integration

\section{INTRODUCTION}

$\mathscr{J}$ he Economic Community of West African States (ECOWAS) was a concept founded and deeply rooted in the market and economic integration of the participating countries, as well as a model frame for the larger, if more ambitious, integration of the entire continent. Effectively implemented, Africa's transition and transformational participation in globalization would have been more significant than is otherwise the case today, with scarcely $1 \%$ of the world's GDP and $2 \%$ of international trade flows and a complete absence in the share of exports in manufactured goods. Paradoxically, more than 25 years after inception, available evidence in the subregion seems to suggest that the original thinking and the projectional expectations have not materialized. The question is: what may be responsible for this apparent failure in goal realization? It is the objective of this paper to evaluate the most critical of these constraints and to assess whether ECOWAS, as an economic union, is viable and sustainable. It is our hope that by examining some of these constraints and addressing and suggesting possible policy options, one would persuade a holistic and more optimistic assessment of the sub-region as an alternative location that is sufficiently attractive in its competitive offer and sensitivity to Foreign Direct Investment. 


\section{PROFILES AND BACKGROUND}

ECOWAS, founded in 1975, is comprised of sixteen nations, ${ }^{1}$ a mix of Anglo-phone, Franco-phone and Lusophone, erstwhile colonial states, all located in sub-Saharan Africa. The main objectives of ECOWAS were the eventual elimination of all tariffs and barriers between member countries, the establishment of customs union, unified fiscal policy and coordinated regional policies in the transport, communication, energy and other infrastructural facilities (CDD, 2002). However, ECOWAS boasts a paltry 60-billion dollar Gross Domestic Product (GDP) and a population of 218 million, which, by the way, is the highest rate of population growth in the world at 2.7 percent. Nigeria, with over 120 million people, accounts for more than half of this population and nearly half of its GDP. The next two largest numbers are Ghana with $8 \%$ of the population and $8 \%$ of GDP, and Cote d'Ivoire with $7 \%$ of population and 12\% of GDP. As of 1998, the average income growth of the community was estimated at $3.9 \%$. Cote d'Ivoire leads the growth rate at about $6.8 \%$ (ECOWAS). The sub region's foreign debt reached $\$ 306$ billion in $\$ 2004$, with some member countries posting a ratio of debt to export of $180.2 \%$ and ratio of debt to GDP of $66.1 \%$. The ECOWAS background is ironically one of lingering, but powerful, erstwhile colonial powers' influence. The result is policies (monetary and fiscal), institutional framework, infrastructural (in)capacity or (in)compatibility and other in-country variables, deeply rooted in colonial antecedents that have significantly impacted market convergence in the sub-regional construct called ECOWAS.

\section{COLONIAL LEGACY WITHIN SUB-REGIONAL CONTEXT}

Although anchored in the presumptuousness of proximity and neighborly African brotherhood, these hitherto scrambled colonial states were not only generally geographically indistinctive. There has been something of a collective post-independence, colonial hangover and umbilical cord inseparability to the erstwhile colonial authorities that was as perniciously enduring, as they were nebulously counter-productive and anti-integration. Indeed, it would appear that the composition of the participating countries and their traditional colonial heritage and allegiance, with its huge and varying socio-cultural peculiarities, would in time, come to count as one of the major stumbling blocks in the effective market and economic integration of the sub-region (Olakanpo, 1965; Boughton, 1991; Schenk, 1993; and Uche, 1997).

Each of the colonial masters---Britain, France, and to a lesser extent, Portugal---who held sway in the subregion, desperately perpetuated and actively caved impenetrable spheres of market and economic interests that were correspondingly isolationist and sub-regionally non- integrative. Because the attainment of independence never translated into the achievement of independence in real terms, the suggestion here is that the combination of the colonial antecedents, inherent and imposed linguistic and cultural differences, and post-independence nationalism have also combined to make most West African countries live in isolation, further making it difficult for a viable and integrated economic community. According to some opinions, “.... artificial borders inherited from colonial powers, and the rivalry over the relative weight and influence of member states, especially Cote d'Ivoire, the most prosperous of the West African Francophone states, and Nigeria as the largest of the Anglophone states. Analysts suggest that Cote d'Ivoire's relations with Nigeria are based on rivalry because the country has a leadership aspiration in the sub-region and therefore sees Nigeria as a stumbling block". (CDD, 2002, 2)

It would appear, therefore, that the pervasive colonial calculation was that its dominant political and economic interests, and what has since come to be accepted usage and practice in that connection, enlightened selfinterest and protection of spheres of national interests and influence, which seems paramount at the critical and relevant time was, even after independence, better served and protected in a non-integrated sub-region than in an integrated one. The French (the most audacious practitioner) delicately referred to this as "Assimilation Policy", which sort to "socially and culturally assimilate" their (French) colonies in West Africa.

It has been noted that the key lesson learned in regional integration around the world was that it was a politically driven process, underpinned by the recognition that indigenous sovereign interests were best advanced through regional actions that are mutually complementary and sustainable (Omar Kabbaj, 2002). Unfortunately, there has been a lack of such cooperation, due in large part to a dual combination of mutually-destructive factors; i.e., a sustained divisive colonial influence and interference on political and economic issues of the former colonies and a hopelessly incompetent and corrupt regional leadership. As earlier noted, each of the colonial participants in 
the sub-region brought to the colonies a distinct and acculturalized, even to this day, subsisting hue of their peculiar economic and development policies, which greatly impacted the sub-regional market environment. By the way, this pattern has not changed much within the sub-region, notwithstanding the current state of the colonials' collective membership and full participation in one of the most successful models of economic integration anywhere in the world--the European Union.

In the self-aggrandized, but extremely competitive environment of their participation, colonials created spheres of influence in the sub-region whose lasting imprimatur is a legacy of lasting colonial institutional dilution and patent isolationism. Understandably, no colonial was therefore disposed to encourage inter-country market integration for fear of ceding "superiority" or "dominance". In the circumstances of the aforesaid environment, it is intrinsically unrealistic to conjecture of sub-regional integration when the critical variables for such exercise were woefully uncomplementary, if not downright unamenable, to complementarity. This entrenched colonial structure is unraveling rather slowly and tediously with evident ineffectiveness.

The point must be made, though, that the allusion to "dominance" of colonial influence must not be misunderstood. Indeed, it should be appreciated within the context of its usage in that the suggestion here is that colonial policy seemed to encourage ambivalent, if not pathetic subservience, in (policy) choices made by the erstwhile colonies' leadership. It is not intended here to absolve the political leadership of the colonial states of their responsibilities and culpabilities regarding policy choices they made; rather to note that their options/choices seemed unabashedly influenced and desperately dependent on some convoluted, even if imposed, dynamism of "superior" attraction and colonial "reward" in the form of competing colonial aids and grant offers.

It would appear that the political leadership that emerged in these countries made market and development policy choices that were either "aid-influenced" or "aid-tied". Others may have been grant-induced. It is therefore doubtful that the policy choices were any more creatively articulative in their market sensitivity, or indeed that sound national imperatives/considerations were a paramount quotient in their articulation, not to mention implementation. It can only be surmised that suffocating colonial antecedents in the sub-region has created enormous challenges for the infant community, including cultural, economic and political obstacles. The overriding question is whether these challenges can be surmounted, to attain a functional and viable integration, in the face of competing colonial influences.

\section{PREVAILING AND COMPETING COUNTRIES' STRUCTURE/FRAMEWORK}

Recent developments in the region, wars and political unrest, have brought to the fore the critical political and economic stability issues and their connection to market development imperatives. Sierra Leone, Cote d'Ivoire, Liberia, Guinea Bissau, and Sudan are good examples of national disruptive experiences, which have had huge subregional implications. Their impact on intra-country commercial transactions and market information are no less significant. "The displacement of large segments of the population, the disruption of normal economic activities, and the deterioration of socio-economic and political infrastructures has had a profound effect on regional cooperation. Cross border transactions in West Africa are severely handicapped by inadequacy of knowledge and information about the markets of neighboring countries, with experience in doing business across borders and lack of reliable, external contacts" (ECOWAS).

It has been suggested that the most important features of a regional configuration are the relative degree of balance and complementarity and the extent to which the component states are oriented toward integrative behavior and sustainable convergence (Feld and Boyd, 1980, 3; Ojo, 2003), and in no area is that feature more significant than the potential for increased trade among participating countries in SSA. There is a relatively low volume of recorded trade transactions between the countries, not unconnected perhaps with poor national data/statistics, state of communication infrastructure, and network of roads. Indeed, the fact that only Nigeria and Cape Verde have more than three times the mileage of paved to non-paved roads relative to other countries is very instructive on inter-trade flows. For the rest of the community members, the ratio is below $0.6 \%$. Even as operationally dysfunctional as Nigerian Railways is in its current state, only Nigeria and Guinea have more than 1000 miles of railway lines. For Niger, The Gambia, Cape Verde and Guinea Bissau, railway lines are completely non-existent. According to the World Bank, in its long-term perspective study on Africa, "The community's organizational structure seems part of 
a subsisting ineffectual framework. At least in its current form, these structures appear to be less participatory and accommodating in design. The current structure of the community, with a relatively unbalanced distribution of economic capabilities, and less than very clear and definitive countries' balance of participation, has made smaller countries less enthusiastic and perhaps apprehensive of fully embracing membership, and hence policies". This contrasts with what Walter Kennes contends is the position with the European Union; i.e., "the European institutional structure was designed to balance the need of large and smaller states...and an important principle governing decision-making in the EU has been the notion of subsidiarity, which ensured that EU decisions were taken at the level at which they were most effective..." $(2002,11)$. This lack of participation is what Adedeji has referred to as "excessively economistic approach" to integration, perhaps in their extreme adherence to orthodox economic approach to integrate. The other issues he points out are significant in their debilitating contradictions: They include (1) "failure of all African countries to achieve significant structural economic transformation, (2) lack of capacity to generate momentum for development and withstand economic shocks, (3) absence of a shared regional political union, value and stability, (4) lack of people-centered integration process, (5) over concentration on choice and structure of institutions, instead of focusing on the substantive issues, and (6) proliferation of institutions with overlapping mandates and tasks" $(2002,9)$.

It is inconceivable to contemplate a regional economic integration in a sub-region that measures woefully on all Human Development Indexes (HDI). Between 1980 and 2002, the World Bank', along with the African Development Bank, provided $\$ 77.5$ billion (in 1995 dollars) in development assistance to the 48 countries in subSaharan Africa--nearly $\$ 1.5$ billion per country - to facilitate economic and market development in the region. The result on ground is one of negligible impact. Indeed, according to the World Bank (Shaefer, 2004), of the 45 subSaharan African countries for which per capita GDP data are available from 1980 to 2002:

- $\quad$ Twenty-three experienced negative compound annual growth in real per capita GDP (constant 1995 U.S. dollars);

- $\quad$ Seven experienced marginal compound annual growth between 0 and 1 percent in real per capita GDP; and

- $\quad$ Fifteen experienced compound annual growth of more than 1 percent in real per capita GDP, but only three achieved per capita growth over 4 percent. The best performer was Equatorial Guinea, which experienced real growth of over 12 percent due to the recent discovery and export of oil (Schaefer, 2004).

The different national policies are no more people-oriented at the national level than they are at the subregional level, and even more so is their lack of coherent complementary articulation. The level of poverty in the sub-region is such that integration policies, especially one that is cognizant of globalization, must be people-oriented (Wangwe, 2002, 14). The surprise is the lack of such sensitivity, demonstrated by the Nigerian experience, which, in a manner of speaking, is replicated across the sub-region. It is a profound case of underfunded and dilapidating educational system, non-existent health care delivery system and chronic unemployment (This Day, 2002). Needless to say, people-oriented initiatives engender and enhance viable human resource development that has huge purchasing power potentials; and when spread across sub-regional boundaries, as it ought, it creates huge markets for goods and services, that is, in turn, attractive to investment capital.

A corollary to the above is a phenomenon, very threatening and urgent, yet barely articulated in the context of its huge significance in terms of human resource development - HIV/AID. Unfortunately, the health sector in the sub-region compares very poorly with the rest of the emerging nations. For instance, in 1997, child and juvenile death rates in Africa were 105 and 169 per 1,000 against 6 and 7 per 1,000, respectively in developed countries. Life expectancy was 48.9 years compared to 77.7 years in developed countries. Only 16 doctors are available per 100,000 inhabitants against 253 in industrialized countries (NEPAD, 2001). Unless there is a harmonized subregional containment of initiatives, the envisaged free movement of people across borders, which Adedeji (2002) has emphasized as "nothing will do Africa greater good than having a passport that every African can have access to", may turn out to be a deadly access for uncontrolled and unmanageable disease transmission across national boundaries.

This situation is made more herculean by the geography and lack of social or cultural homogeneity in the region. According to the world, West Africa is highly fragmented as a result of geographic, demographic, political and policy-related reasons. The 236 million inhabitants are very unevenly distributed among countries.... half the 
total population and several countries having less than one million people. There is no indigenous, widely used language for commerce.... but rather three official European languages, still not understood by large segments of the population. The region is roughly one-third desert, one-third Sudano Sahelian ... nearly half of the area is formed by landlocked countries. Internal distances, as well as distances to core markets (about 50 percent greater than in East Asia), are enormous and transport infrastructure networks are only partially interconnected between countries since they had been originally conceived to serve the colonial interests rather than the region's, and they are very poorly maintained. Because of natural obstacles, political fragmentation, and inappropriate polices, national markets are tiny and regional markets remain undeveloped. As a result, infrastructure costs are among the highest in the world; electricity costs are, on average, 4.5 times higher than in the OECD countries and two times higher than in Latin America. The rates for international telephone calls are about four times higher than in OECD and 2.5 times higher than in Latin America..." (World Bank, 2001, 2).

\section{CONTENDING PARADIGMS OF THE MARKET ENVIRONMENT}

Notwithstanding the expectation of full integration at inception of ECOWAS, by the members, there existed separate and mutually competing institutional structures that would, at best, make integration tenuous and, at worst, unrealizable. It is perhaps within these contexts that one is able to appreciate the comments of Kabbaj that "Effective regional institutions will be critical for the sustainability and effectiveness of any efforts at improving regional integration and economic cooperation" $(2002,4)$. Unfortunately, those institutions are woefully inadequate, if not totally lacking.

The sub-region has the highest concentration of poor countries of any regional integration experiment in the world, and with it, all the negative attributes of zonal and concentrated poverty. Without doubt, therefore, it is theoretically perhaps the grouping that is least likely to succeed in establishing a functional and beneficial integration zone (World Bank, 2000; Masson and Pattillo, 2001; Uche, 2002). Apart from its myriad of inhibiting institutional problems, the zone appears incapable of establishing an optimum currency area upon which the success or failure of any integration experiment critically depends. For instance, there are nine different currencies in the sub-region with seven of the sixteen countries having a common currency tied to France - CFA franc.

There is also the problem of intra-ECOWAS trade and level of investment, and by extension, the subregion's meaningful participation in globalization. "ECOWAS' trade amounts to approximately $11 \%$ of the subregion's total trade with the world...intra-community trade stood at $\$ 1,813$ million for total imports and $\$ 2,539$ million for total exports. Compare this with the region's import from, and export to, Europe of $\$ 7,525$ million and $\$ 8,114$ million, respectively, for 1997" (CDD, 2002).

The need for fiscal policy harmonization cannot be overemphasized. The relative inconvertibility of regional currencies and the scarcity of foreign exchange makes the situation much more difficult (CDD, 2002, 6). There appears to be an absolute lack of intra-country harmonization. According to some opinions, externalities at country level, linkages between fiscal, monetary, and exchange rate policies should be reason enough to avoid tax competition among member countries, since that may not only inhibit the formation of an optimum currency area and price stability, but sub-regional mobility of labor (Geda, 2002; Korsaga, 2002). Indeed, the establishment of such an area would, among other things, depend on high mobility of factors of production, openness to trade, high level of intra and inter-state trade, and high degree of product and export diversification, unaffected by exogenous and endogenous shocks (Mundell, 1961; Wampah, 2001; Feldman et al, 1998).

The creation of the West African Clearing House (WACH) is an example of a structure that was intended to promote trade and exchanges among member countries that did not live up to its billings. It is generally believed that it had failed in this rather modest goal due to discrepant policy initiative or framework of the two zones. It would appear that notwithstanding a yet to be fully consummated WACH, West Africa Monetary Agency (WAMA), a much more complicated, if audacious initiative, was launched. In the main, WAMA was supposed to initiate and implement the ECOWAS Monetary Cooperation Programme -EMCP- (Uche, 2002), even as it seemed woefully unable to engineer or persuade a functional and compatible integration. 
The creation of the West African Economic and Monetary Union (UEMOA) in 1994 by the Franco-phone member countries (CFA zone) seems to work at cross-purposes, since they were intended to strengthen their political, economic and monetary cooperation amongst themselves on the one hand and with France on the other, thus isolating and further weakening a rather tenuous integration experiment.

Even the on-going programme for the establishment of a second monetary zone appears to have similar inhibitions as the first attempt, including the absence of an external and efficient agency of restraint in the enforcement of WACH regulations. Unfortunately, WAMA, to date, has not been able to implement these new initiatives. The demands of this new initiative are as economically daunting as they are pathetically tasking. The adjustments and constraints they demand are uncomfortably reminiscent of the IMF conditionalities of the Structural Adjustment Programme (SAP).

It is difficult to see how very poor countries can adhere to strict convergence criteria capable of, at least sometimes, causing social upheaval at home, unless a strong agency of restraint can enforce compliance, and such compliance is devoid of indigenous political risk. Although a Stabilization Cooperation Fund has been set up under the WAMA programme, this simply may not be enough as its functional sustainability is doubtful (Uche, 2002). For example, the size of Nigeria, relative to its neighbors and what has come to be regarded as the country's perennial extra-budgetary indulgences can be a problem if the country decides to avail itself of the facility. Indeed this specter may have compelled IMF cautionary advice against the country's participation in a common currency zone (This Day, 2003).

Even though the suggestion is that integration needs a dominant economy to drive the process forward, the question is whether Nigeria, with its correspondingly contradictory attributes and potentials, fits that billing. The prevalent perception is one of profound doubt. Masson \& Patillo succinctly touched on an area of concern which could derail and weaken further - the yet-to-be functional Union when they pointed out that the six non-WAEMU countries in ECOWAS have announced their intention to set up a compensation fund to make transfers among countries of the monetary union. In the past, some countries have not paid their dues to the ECOWAS institutions for many years... given the size of Nigeria relative to its neighbors, the operation of such a fund may well be asymmetric. Transfers to the smaller countries, if they get into difficulties, could be sizable; but if Nigeria were to draw, it could quickly exhaust available resources of the fund (Masson and Pattillo, 2001b, p.13).

\section{CONCLUSION}

ECOWAS, as we know it today, after 25 years of its birth is at best struggling and yet to demonstrate that it has what it takes to become a success in its original intent or as a viable economic union.

Effective economic integration (substantially lacking at present), we believe, requires the development of core human "facilitators" as well as institutional and infrastructural convergence and compatibility in functional market structures.

ECOWAS, despite all attempts, has failed to realize any measure of real success in its dream of integration. ECOWAS, in our judgment, is much further away from that goal, as evident from its various poorly articulated policies, failed deadlines and uncompleted/unfinished, and, in some cases, failed enabling environment and structures, such as the WACH, WAMA and EMCP.

The chances of ECOWAS emerging as a true, functional and sustainable economic union remains elusive and doubtful. Deep rooted conflicting interests, significant priority differences among member countries, continued allegiance to the controlling forces of these countries' "colonial masters" in the developed countries, and lack of homogeneity in language and culture will continue to become major constraints, constraints that the organization and its members do not a appear to be capable of surmounting. Although the hopes remain alive and high among some members seriously committed to the success of ECOWAS, the reality on the ground of a truly functioning common market or union is very doubtful. At best, one can only look forward to a dream yet to be realized and/or a loose union comprising of sub-regional multilateral cooperation not significantly different from those presently in existence and drawn along old colonial relationships and/or similarities. 


\section{AUTHOR INFORMATION}

Darlington Richards is an Associate Professor of Management and International Business in Earl Graves School of Business and Management, at the Morgan State University Baltimore, MD U.S.A. His research interests include privatization and Market deregulation, Market Reform and Change Management, Law Reform for Emerging Economies and Ethics in Business. He has published extensively in these areas, in several refereed journals and book chapters. Dr. Richards serves as a Reviewer to some journals and publishers.

Gladson I. Nwanna is a former consultant to the World Bank and a Professor of Finance in Earl Graves School of Business and Management, at the Morgan State University, Baltimore, MD U.S.A. He has authored several books as well as published several papers in refereed academic journals.

\section{ENDNOTES}

At the time ECOWAS was registered in Nigeria in May 1975, there were 15 members in the organization to start with. In 1976, Cape Verde joined ECOWAS as $16^{\text {th }}$ member. In 2002, Mauritania left the organization. Currently, there are 15 member countries in the organization namely, Benin, Burkina Faso, Cape Verde, Côte d'Ivoire, Gambia, Ghana, Guinea, Guinea-Bissau, Liberia, Mali, Niger, Nigeria, Senegal, Sierra Leone, and Togo.

\section{REFERENCES}

1. Adedeji (2002) “Defining Priorities for Regional Integration” Economic Commission for Africa. March 38, 2002.

2. Boughton, J.M. (1991), The CFA Franc Zone: Currency Union and Monetary Standard, International Monetary Fund Working Paper Number WP/91/133 (Washington D.C., International Monetary Fund).

3. Curry, James. (1999), Regionalisation in Africa" in Bach D. (ed.) Oxford.

4. Feld, Werner J. and Boyd, Gavin. (1980), "The Comparative Study of International Regions" in Feld and Boyd (eds), Comparative Regional Systems: West East Europe, North America, The Middle East and Developing Countries. Pergamon Press, New York.

5. Feldman, R., Nashashibi, K., Nord, R., Allum, P., Desruelle, D., Enders, K., Kahn, R. and TempranoArroyo, H. (1998), Impact of EMU on Selected Non European Union Countries, International Monetary Fund Occasional Paper Number 174 (Washington DC, International Monetary Fund).

6. $\quad$ ECOWAS a. http://departments.oxy.edu/dwa/201/atlas/ecowas/ecowas.html

7. Masson, P. and Pattillo, C. (2001a), Monetary Union in West Africa (ECOWAS): Is it Desirable and How Could it be Achieved? International Monetary Fund Occasional Paper Number 204.

8. Mundell, R. (1961), A Theory of Optimum Currency Areas, American Economic Review, Volume 51, pp.6509-517).

9. Olakanpo, O. (1965), Central Banking in the Commonwealth (Calcutta, Bookland Private Limited).

10. Ojo, M. (2003), "To Establish a Common Central Bank with a Single Currency for Economic Prosperity of West African Monetary Zone". http://www.wami_imoa.org.

11. Schaefer, Brett D. (2004), "Multilateral Economic Development Efforts in Sub-Saharan Africa" Heritage Lecture \#858

12. Schenk, C (1993), The Origins of a Central Bank in Malaya and the Transition to Independence, 1954-59, The Journal of Imperial and Commonwealth History, Volume 21, pp. 409-431.

13. This Day, Nigeria, 2003

14. This Day, Nigeria, 2004

15. Sharer, R. (1999), "Trade: An Engine of Growth for Africa”, Finance and Development. December.

16. Uche, C.U. (1997) Bank of England Vs The IBRD: Did the Nigerian Colony Deserve a Central Bank? Explorations in Economic History 34: 220-241.

17. Uche, C.U. (2002), "Can African Institutions Finance African Development? Evidence from the ECOWAS Fund", Paper Presented at the CODESRIA and Third World Network (Africa) Conference on Africa and the Development Challenges of the New Millennium (Accra, Ghana, $23^{\text {rd }}$ to $26^{\text {th }}$ April 2002).

18. Wampah, H. (2001), A Critical Appraisal of Economic Integration Process in the West African SubRegion, West African Journal of Monetary and Economic Integration, Volume 1, Number 1, pp. 1-12. 
19. West Africa \& World Index (1999), Vol. V. No. 3.

20. The World Bank (2001), Memorandum of the President of the International Development Association to the Executive Directors, on Regional Integration Assistance Strategy for West Africa.

\section{NOTES}

